\title{
Changes over time in means of suicide in Canada: an analysis of mortality data from 1981 to 2018
}

\author{
Li Liu MSc, Colin A. Capaldi PhD, Heather M. Orpana PhD, Mark S. Kaplan DrPH, Lil Tonmyr PhD
}

Cite as: CMAJ 2021 March 8;193:E331-8. doi: 10.1503/cmaj.202378

\begin{abstract}
BACKGROUND: Ongoing surveillance of the means of suicide is necessary for effective prevention. We examined how mortality rates owing to different means of suicide changed in Canada from 1981 to 2018.
\end{abstract}

METHODS: We obtained data from 1981 to 2018 on suicide deaths of individuals aged 10 years and older, from the Canadian Vital Statistics Death Database. We used joinpoint regression analysis to examine changes over time in the suicide mortality rate for the 3 most common means of suicide.
RESULTS: The age-standardized suicide mortality rate declined in earlier decades for both sexes, but did not significantly change in recent decades for either sex. The age-standardized rate of suicide by suffocation increased from 1993 for females (2.1\% per year) and from 1996 for males ( $0.4 \%$ per year). The age-standardized rate of suicide by poisoning decreased for females (2.2\% per year) and males (2.1\% per year) from 1981 to 2018 . The age-standardized rate of suicide by firearm decreased from 1981 to 2008 (7.4\% per year) but did not significantly change thereafter for females; for males, it decreased
2.1\% per year from 1981 to 1993 and 5.7\% per year from 1993 to 2007, but did not significantly change thereafter.

INTERPRETATION: For both sexes, the rate of suicide by poisoning is decreasing, the rate of suicide by suffocation is increasing, and the rate of suicide by firearm has not significantly changed in the last decade. Given the high proportion of suicide deaths by suffocation, its increasing rate and the difficulty of restricting the means of suffocation, other approaches to suicide prevention are needed.

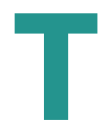

he overall suicide mortality rate in Canada is lower than it was a few decades ago, but continued declines have been absent in recent years and the impact of suicide remains high. ${ }^{1,2}$ Suicide was the ninth leading cause of death in 2018. ${ }^{3}$ More than three-quarters of suicide deaths in Canada are a result of suffocation, poisoning and firearms. ${ }^{4-6}$ Suffocation is the predominant suicide method in most countries. ${ }^{4}$ However, the prevalence of different means of suicide can vary over time because of changes in the accessibility of certain means. ${ }^{7}$ Evidence suggests that the relative frequency of different means of suicide has changed in Canada, but those studies have not included data from more recent years. ${ }^{8,9}$ Ongoing surveillance of the means of suicide and understanding changes over time are essential for designing and implementing prevention programs. ${ }^{10}$

It is especially important to consider sex and age in suicide surveillance, because of differences across these sociodemographic characteristics. For instance, females are more likely to self-report thoughts of suicide and to be admitted to hospital owing to self-inflicted injuries, ${ }^{5,11}$ while suicide mortality rates are about 3 times higher among males than females in Canada. ${ }^{2,3,6}$ Higher suicide mortality rates for males have been observed in almost all countries, ${ }^{1}$ and have been attributed, in part, to more lethal means of suicide (e.g., firearms)..$^{5,6,12}$ Suicide-related behaviour also varies across the lifespan, with the suicide mortality rate tending to be high in middle-aged adults and males older than 80 years, but hospital admissions owing to selfinflicted injuries tending to occur during adolescence (particularly among females)..$^{2,3,5,6,13}$

Canadian data from 2000 to 2009 indicated that suicide by suffocation was more prevalent among individuals aged 15-39 years, while suicide by firearm was more prevalent among individuals aged 60 years and older. ${ }^{6}$ Canadian data for 2001 to 2011 suggested that rates of suicide by firearm and poisoning declined for males aged 15 years and older, but were unchanged among females during this period. ${ }^{9}$ Less is known about whether the means used by age and sex groups have fluctuated over longer periods and in more recent years. We sought to document the means of suicide deaths in Canada in 2018 (the most recent data available at the 
time of writing) and investigate how the use of different means has changed for males and females and across age groups since 1981.

\section{Methods}

\section{Data sources}

We analyzed data from 1981 to 2018 on suicide deaths of individuals aged 10 years and older, from the Canadian Vital Statistics Death Database. We identified suicide deaths from 1981 to 1999 using diagnostic codes E950-E959 from the International Classification of Diseases, 9th Revision (ICD-9), and 2000 to 2018 using diagnostic codes X60-X84 and Y87.0 from the International Statistical Classification of Diseases and Related Health Problems, 10th Revision (ICD10). ${ }^{14}$ Comparability studies suggest ICD coding changes did not substantially affect the number of deaths classified as suicides. ${ }^{14,15}$ We grouped means of suicide into the following categories: hanging, strangulation or suffocation (E953, X70); poisoning (E950-E952, X60X69); firearms or explosives (E955, X72-X75); falls (E957, X80); cutting or piercing (E956, X78-X79); and other (all other codes). We obtained data for 1981 to 1999 through a data-sharing agreement between the Public Health Agency of Canada and Statistics Canada; data for 2000 to 2018 are available online. ${ }^{16}$ We used population estimates from Statistics Canada to calculate mortality rates. ${ }^{17}$

\section{Statistical analysis}

We calculated age-standardized suicide mortality rates per 100000 population by the direct method, using the 2011 population as the standard population. We calculated crude mortality rates for agestratified analyses. We analyzed changes in suicide mortality over time using the Joinpoint Regression Program Version 4.7.0.0. ${ }^{18}$
Joinpoint regression analysis models time trends using segmented linear regression. The method identifies changes in the slope of the regression function, determining the number and location of these changes (i.e., join points). We calculated the annual percent change (APC) to interpret the rate change per year using the formula

$\mathrm{APC}=[\exp (\beta)-1] \times 100$

where $\beta$ is the regression coefficient of log suicide mortality rate on year. We computed the average annual percent change (AAPC) from 1981 to 2018 by the weighted average of the APCs, with the weights equal to the length of the segments (i.e., the number of years) from the joinpoint model. We obtained 95\% confidence intervals (Cls) for the APC and AAPC estimates. We investigated changes over time for the 3 most common means of suicide in Canada (i.e., suffocation, poisoning and firearm) at the national level and stratified by sex (female and male) and by age (10-19, $20-34,35-64$, and $65 \mathrm{yr}$ or older). We chose these age groups to represent adolescents, young adults, middle-aged adults and older adults. For nonstratified analyses, we used a $p$ value of 0.05 as the cut-off for statistical significance. For the stratified analyses, we applied Bonferroni corrections for multiple comparisons. For sex-stratified analyses, we used a $p$ value of 0.025 ; for analyses stratified by sex and by age, we used a $p$ value of 0.005 .

\section{Results}

\section{Suicide deaths in 2018}

Figure 1 presents the age-standardized suicide mortality rates and the number of deaths from each of the means of suicide in 2018. According to the data, suicide by suffocation was more prevalent than other means, for both males and females. For

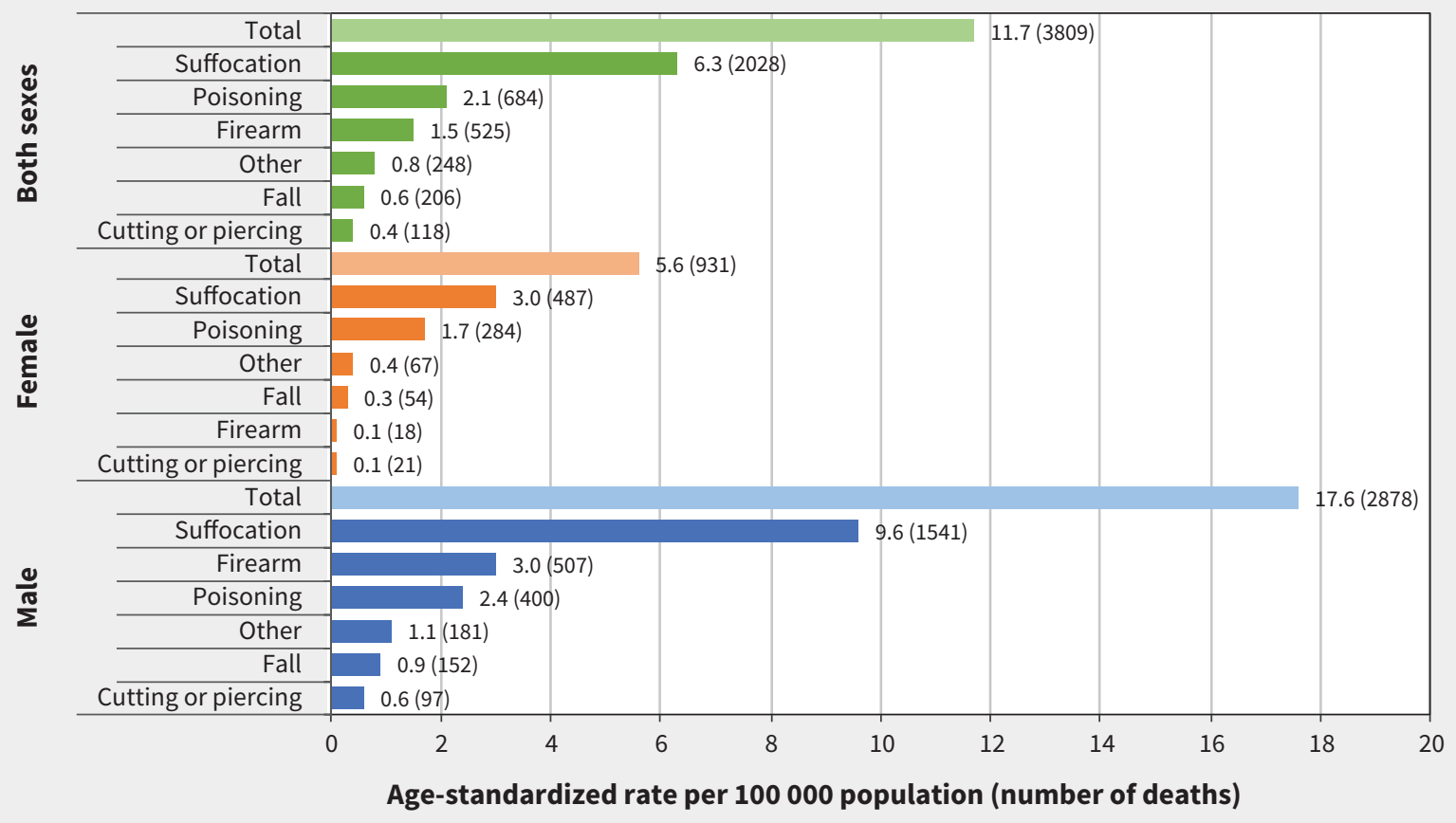

Figure 1: Age-standardized suicide mortality rates (and number of deaths) by means of suicide (suffocation, hanging or strangulation; poisoning; firearms or explosives; falls; cutting or piercing; and other) in Canada, 2018. 
males, the age-standardized mortality rate of suicide by suffocation (9.6 per 100000 population) was 3.2 times higher than that for firearms (3.0 per 100000 population) and 4.0 times higher than that for poisoning (2.4 per 100000 population). For females, the age-standardized mortality rate of suicide by suffocation (3.0 per 100000 population) was almost 1.8 times higher than that for poisoning (1.7 per 100000 population) and 30 times higher than that for firearms ( 0.1 per 100000 population). Agestandardized suicide mortality rates for males exceeded those for females across each of the 6 examined means of suicide.

\section{Changes in the suicide mortality rate}

Table 1 presents all of the estimates from the joinpoint analyses. A total of 142343 suicide deaths of individuals aged 10 years and older occurred in Canada from 1981 to 2018. Overall, we observed a significant decrease in Canada's age-standardized suicide mortality rate from 1981 to 2008 (1.2\% per year), but no significant changes after that. As plotted in Figure 2, we also observed a plateauing when we examined males and females separately. For females, the overall age-standardized suicide mortality rate decreased significantly from 1981 to 1991 (by 3.3\% per year), but did not change significantly after that. For males, the overall agestandardized suicide mortality rate decreased significantly from 1981 to 1999 (by 0.6\% per year), but did not change significantly after that. Mean-specific changes over time are plotted in Figure 3, and Appendix 1, Figures S1-S8 (available at www.cmaj.ca/ lookup/doi/10.1503/cmaj.202378/tab-related-content).

\section{Change in means of suicide}

\section{Suffocation}

The age-standardized mortality rate of suicide by suffocation increased significantly for both males and females in recent decades, although the magnitude of this increase differs (Appendix 1, Figure S1). For females, the increase has been consistent and significant from 1993 to 2018 at 2.1\% per year, but for males it increased significantly from 1988 to 1996 (by $4.1 \%$ per year) and by $0.4 \%$ per year afterward. As shown in Appendix 1, Figure S2, a rising crude mortality rate of suicide by suffocation in more recent periods was apparent across almost all age groups of females, except for those aged 65 years and older, among whom this suicide mortality rate declined significantly (1.9\% per year) across the 38-year range of this study. The crude rate of suicide by suffocation has been increasing faster for females aged $10-19$ years (2.8\% per year since 1995) and 20-34 years (3.7\% per year since 1981) than for females aged 35-64 years (1.5\% per year since 1994). In age-stratified analyses, we observed a significantly increasing crude mortality rate of suicide by suffocation in men aged $35-64$ years (0.6\% per year since 1999), but it declined significantly since 1997 (by 1.2\% per year) for males aged 10-19 years and since 1981 (by $0.8 \%$ per year) for males aged 65 years and older (Appendix 1, Figure S3).

\section{Poisoning}

From 1981, the age-standardized mortality rate of suicide by poisoning decreased by an average of $2.2 \%$ per year for females and $2.1 \%$ per year for males (Appendix 1, Figure S4). Among females younger than age 65 years, crude mortality rates of suicide by poisoning declined significantly recently (Appendix 1, Figure S5). By contrast, from 2000, for females aged 65 years and older, the crude rate increased significantly, by $1.8 \%$ per year. Among males in all age groups, the most recent trends for poisoning decreased significantly (Appendix 1, Figure S6).

\section{Firearms}

Over the 38 years of data examined in this study, the agestandardized mortality rate of suicide by firearm fell by an average of $5.2 \%$ per year among females, and by an average of $3.1 \%$ per year among males. However, these reductions occurred primarily in earlier decades (see Appendix 1, Figure S7 for the overall sex-stratified firearm results). From 1981 to 2008, the agestandardized mortality rate of suicide by firearm for females fell by $7.4 \%$ per year, but did not change significantly thereafter. Similarly, this rate for males decreased significantly from 1981 to 1993 (by 2.1\% per year) and from 1993 to 2007 (by 5.7\% per year), but did not change significantly thereafter. However, differences in age-specific patterns of firearm suicide mortality were observed among males (see Appendix 1, Figure S8). The crude rate decreased consistently and significantly from 1981 for males aged 65 years and older (by $2.4 \%$ per year), and decreased across most of the study period for males aged 35-64 years (except from 2008-2015, when no significant change occurred). Younger males also had significantly decreasing crude mortality rates for suicide by firearm in earlier decades, but the crude rate did not change significantly from 2004 for males aged 10-19 years, and it increased significantly from 2008 for males aged 20-34 years (by $2.4 \%$ per year). Given the small number of suicide deaths by firearm among females (i.e., around 0.4 per 100000 population after 2012), we did not conduct joinpoint analyses of age groups.

\section{Interpretation}

In this study of patterns in suicide deaths in Canada over almost 4 decades, we found that the rate of suicide by suffocation is generally increasing, while that for poisoning is decreasing. The rate of suicide by firearm had been declining, but we observed no significant changes in recent years among both sexes. These trends tended to prevail across age groups, although there were some exceptions.

The increasing rate of suicide by suffocation among some sociodemographic groups in Canada may partially explain why the overall suicide rate has not continued to decrease in recent years. ${ }^{2}$ Increasing rates of suicide by suffocation have also been observed in other countries; for instance, Norway and the United States. ${ }^{19,20}$ Recent Canadian research reported rising suicide rates among females aged 10-24 and 45-64 years. ${ }^{2}$ Our research suggests that this may reflect rising rates of suicide by suffocation among females younger than 65 years. Substitution of less lethal means of suicide (e.g., poisoning) with more lethal ones (e.g., suffocation) over time among younger females might explain this increase. ${ }^{21}$

We found a decrease in poisoning suicide rates among almost all sociodemographic groups examined. The overall decrease coincides with increases in unintentional poisoning deaths observed during parts of the same time period, which might indicate that 
some intentional poisoning deaths are being misclassified as unintentional. ${ }^{9,22}$ Decreases in the rate of suicide by firearm in earlier decades have been attributed, in part, to passage of firearms legislation in 1977 and $1991 .{ }^{23}$ Although the rate of suicide by firearm and the overall suicide rate have been increasing in the US over the past decade, ${ }^{24}$ these rates have not shown any significant changes in Canada over the same time period.

\section{Limitations}

There are several limitations to this study. Discussion of potential drivers of the observed trends is speculative, as the analyses are purely descriptive. The joinpoint regression analyses were limited to describing segments of linear trends, which may be an oversimplification. Moreover, the optimum number of join points was based on statistical significance, which could have resulted in overfitting. Another limitation is the different editions of the ICD used, from 1981 to 1999 and from 2000 to 2018, which could arguably explain some of the trend changes observed during the period of transition. Caution is also warranted when interpreting findings related to poisoning because of the difficulty of establishing intent in poisoning deaths, the potential misclassification of some suicide deaths as unintentional poisoning, and changes in

\section{Table 1 (part 1 of 2): Results from joinpoint analyses of suicide mortality rates in Canada by means, sex and age, 1981-2018}

\begin{tabular}{|c|c|c|c|c|c|c|c|c|c|}
\hline & & & Trend 1 & Trend 2 & Trend 3 & Trend 4 & Trend 5 & Trend 6 & \\
\hline Mean & Sex & $\begin{array}{c}\text { Age } \\
\text { group, } \\
\text { yr }\end{array}$ & $\begin{array}{c}\text { Years } \\
\text { APC } \\
(95 \% \mathrm{Cl})\end{array}$ & $\begin{array}{c}\text { Years } \\
\text { APC } \\
(95 \% \mathrm{Cl})\end{array}$ & $\begin{array}{c}\text { Years } \\
\text { APC } \\
(95 \% \mathrm{Cl})\end{array}$ & $\begin{array}{c}\text { Years } \\
\text { APC } \\
(95 \% \mathrm{Cl})\end{array}$ & $\begin{array}{c}\text { Years } \\
\text { APC } \\
(95 \% \mathrm{Cl})\end{array}$ & $\begin{array}{c}\text { Years } \\
\text { APC } \\
(95 \% \mathrm{Cl})\end{array}$ & AAPC \\
\hline \multirow[t]{3}{*}{ All means } & Both & All & $\begin{array}{c}1981-2008 \\
-1.2^{*} \\
(-1.4 \text { to }-1.0)\end{array}$ & $\begin{array}{c}2008-2015 \\
0.9 \\
(-1.1 \text { to } 3.1)\end{array}$ & $\begin{array}{c}2015-2018 \\
-4.3 \\
(-10.0 \text { to } 1.8)\end{array}$ & - & - & - & $\begin{array}{c}-1.0^{*} \\
(-1.7 \text { to }-0.4)\end{array}$ \\
\hline & Female & All & $\begin{array}{c}1981-1991 \\
-3.3^{\star} \\
(-4.6 \text { to }-2.0)\end{array}$ & $\begin{array}{c}1991-2018 \\
0.1 \\
(-0.2 \text { to } 0.4)\end{array}$ & - & - & - & - & $\begin{array}{c}-0.8^{\star} \\
(-1.2 \text { to }-0.4)\end{array}$ \\
\hline & Male & All & $\begin{array}{c}1981-1999 \\
-0.6^{\star} \\
(-1.0 \text { to }-0.3)\end{array}$ & $\begin{array}{c}1999-2004 \\
-3.1 \\
(-6.7 \text { to } 0.5)\end{array}$ & $\begin{array}{c}2004-2018 \\
-0.3 \\
(-0.8 \text { to } 0.3)\end{array}$ & - & - & - & $\begin{array}{c}-0.8^{*} \\
(-1.4 \text { to }-0.3)\end{array}$ \\
\hline \multirow[t]{11}{*}{$\begin{array}{l}\text { Suffocation, } \\
\text { hanging or } \\
\text { strangulation }\end{array}$} & Both & All & $\begin{array}{c}1981-1990 \\
-0.7 \\
(-2.2 \text { to } 0.8)\end{array}$ & $\begin{array}{c}1990-1995 \\
6.2^{\star} \\
(0.9 \text { to } 11.7)\end{array}$ & $\begin{array}{c}1995-2018 \\
0.7^{\star} \\
(0.4 \text { to } 1.1)\end{array}$ & - & - & - & $\begin{array}{c}1.1^{\star} \\
(0.3 \text { to } 1.9)\end{array}$ \\
\hline & Female & All & $\begin{array}{c}1981-1990 \\
-3.7^{\star} \\
(-5.6 \text { to }-1.8)\end{array}$ & $\begin{array}{c}1990-1993 \\
13.0 \\
(-9.0 \text { to } 40.3)\end{array}$ & $\begin{array}{c}1993-2018 \\
2.1^{*} \\
(1.6 \text { to } 2.5)\end{array}$ & - & - & - & $\begin{array}{c}1.5 \\
(-0.3 \text { to } 3.3)\end{array}$ \\
\hline & & $10-19$ & $\begin{array}{c}1981-1995 \\
13.3^{\star} \\
(9.5 \text { to } 17.2)\end{array}$ & $\begin{array}{c}1995-2018 \\
2.8^{\star} \\
\text { (1.2 to } 4.5)\end{array}$ & - & - & - & - & $\begin{array}{c}6.7^{\star} \\
\text { (5.0 to } 8.3)\end{array}$ \\
\hline & & $20-34$ & $\begin{array}{c}1981-2018 \\
3.7^{\star} \\
\text { (3.3 to } 4.1 \text { ) }\end{array}$ & - & - & - & - & - & $\begin{array}{c}3.7^{\star} \\
\text { (3.3 to } 4.1 \text { ) }\end{array}$ \\
\hline & & $35-64$ & $\begin{array}{c}1981-1990 \\
-5.9^{\star} \\
(-8.5 \text { to }-3.3)\end{array}$ & $\begin{array}{c}1990-1994 \\
12.1 \\
(-3.7 \text { to } 30.4)\end{array}$ & $\begin{array}{c}1994-2018 \\
1.5^{\star} \\
(0.9 \text { to } 2.1)\end{array}$ & - & - & - & $\begin{array}{c}0.7 \\
(-1.0 \text { to } 2.5)\end{array}$ \\
\hline & & $65+$ & $\begin{array}{c}1981-2018 \\
-1.9^{\star} \\
(-2.5 \text { to }-1.2)\end{array}$ & - & - & - & - & - & $\begin{array}{c}-1.9^{\star} \\
(-2.5 \text { to }-1.2)\end{array}$ \\
\hline & Male & All & $\begin{array}{c}1981-1988 \\
-0.8 \\
(-2.9 \text { to } 1.3)\end{array}$ & $\begin{array}{c}1988-1996 \\
4.1^{*} \\
(1.9 \text { to } 6.4)\end{array}$ & $\begin{array}{c}1996-2018 \\
0.4^{\star} \\
(0.004 \text { to } 0.8)\end{array}$ & - & - & - & $\begin{array}{c}0.9^{\star} \\
(0.3 \text { to } 1.6)\end{array}$ \\
\hline & & $10-19$ & $\begin{array}{c}1981-1997 \\
3.0^{\star} \\
(1.5 \text { to } 4.6)\end{array}$ & $\begin{array}{c}1997-2018 \\
-1.2^{\star} \\
(-2.2 \text { to }-0.2)\end{array}$ & - & - & - & - & $\begin{array}{c}0.6 \\
(-0.2 \text { to } 1.5)\end{array}$ \\
\hline & & $20-34$ & $\begin{array}{c}1981-1995 \\
4.2^{*} \\
\text { (3.1 to } 5.3 \text { ) }\end{array}$ & $\begin{array}{c}1995-2018 \\
-0.5 \\
(-1.0 \text { to } 0.01)\end{array}$ & - & - & - & - & $\begin{array}{c}1.2^{\star} \\
(0.8 \text { to } 1.7)\end{array}$ \\
\hline & & $35-64$ & $\begin{array}{c}1981-1988 \\
-2.4^{*} \\
(-4.4 \text { to }-0.4)\end{array}$ & $\begin{array}{c}1988-1999 \\
5.2^{\star} \\
(4.0 \text { to } 6.5)\end{array}$ & $\begin{array}{c}1999-2018 \\
0.6^{\star} \\
(0.2 \text { to } 1.1)\end{array}$ & - & - & - & $\begin{array}{c}1.4^{\star} \\
(0.8 \text { to } 2)\end{array}$ \\
\hline & & $65+$ & $\begin{array}{c}1981-2018 \\
-0.8^{\star} \\
(-1.2 \text { to }-0.5)\end{array}$ & - & - & - & - & - & $\begin{array}{c}-0.8^{\star} \\
(-1.2 \text { to }-0.5)\end{array}$ \\
\hline
\end{tabular}


Table 1 (part 2 of 2): Results from joinpoint analyses of suicide mortality rates in Canada by means, sex and age, 1981-2018*

\begin{tabular}{|c|c|c|c|c|c|c|c|c|c|}
\hline & & & Trend 1 & Trend 2 & Trend 3 & Trend 4 & Trend 5 & Trend 6 & \\
\hline Mean & Sex & $\begin{array}{l}\text { Age } \\
\text { group, } \\
\text { yr }\end{array}$ & $\begin{array}{c}\text { Years } \\
\text { APC } \\
(95 \% \mathrm{Cl})\end{array}$ & $\begin{array}{c}\text { Years } \\
\text { APC } \\
(95 \% \mathrm{Cl})\end{array}$ & $\begin{array}{c}\text { Years } \\
\text { APC } \\
(95 \% \mathrm{Cl})\end{array}$ & $\begin{array}{c}\text { Years } \\
\text { APC } \\
(95 \% \mathrm{Cl})\end{array}$ & $\begin{array}{c}\text { Years } \\
\text { APC } \\
(95 \% \mathrm{Cl})\end{array}$ & $\begin{array}{c}\text { Years } \\
\text { APC } \\
(95 \% \mathrm{Cl})\end{array}$ & AAPC \\
\hline \multirow[t]{11}{*}{ Poisoning } & Both & All & $\begin{array}{c}1981-2015 \\
-1.5^{\star} \\
(-1.7 \text { to }-1.2)\end{array}$ & $\begin{array}{c}2015-2018 \\
-9.3^{\star} \\
(-17.3 \text { to }-0.5)\end{array}$ & - & - & - & - & $\begin{array}{c}-2.1^{\star} \\
(-2.9 \text { to }-1.4)\end{array}$ \\
\hline & Female & All & $\begin{array}{c}1981-1998 \\
-2.8^{\star} \\
(-3.4 \text { to }-2.1)\end{array}$ & $\begin{array}{c}1998-2015 \\
0.3 \\
(-0.4 \text { to } 1.1)\end{array}$ & $\begin{array}{c}2015-2018 \\
-12.6^{\star} \\
(-20.7 \text { to }-3.6)\end{array}$ & - & - & - & $\begin{array}{c}-2.2^{\star} \\
(-3.1 \text { to }-1.3)\end{array}$ \\
\hline & & $10-19$ & $\begin{array}{c}1981-2018 \\
-3.2^{\star} \\
(-5.0 \text { to }-1.4)\end{array}$ & - & - & - & - & - & $\begin{array}{c}-3.2^{\star} \\
(-5.0 \text { to }-1.4)\end{array}$ \\
\hline & & $20-34$ & $\begin{array}{c}1981-2018 \\
-3.1^{\star} \\
(-3.5 \text { to }-2.6)\end{array}$ & - & - & - & - & - & $\begin{array}{c}-3.1^{\star} \\
(-3.5 \text { to }-2.6)\end{array}$ \\
\hline & & $35-64$ & $\begin{array}{c}1981-1998 \\
-2.2^{\star} \\
(-2.9 \text { to }-1.4)\end{array}$ & $\begin{array}{c}1998-2015 \\
0.5 \\
(-0.3 \text { to } 1.4)\end{array}$ & $\begin{array}{c}2015-2018 \\
-15.8^{\star} \\
(-24.9 \text { to }-5.5)\end{array}$ & - & - & - & $\begin{array}{c}-2.1^{\star} \\
(-3.1 \text { to }-1.1)\end{array}$ \\
\hline & & $65+$ & $\begin{array}{c}1981-2000 \\
-3.6^{\star} \\
(-5.0 \text { to }-2.2)\end{array}$ & $\begin{array}{c}2000-2018 \\
1.8^{\star} \\
(0.2 \text { to } 3.4)\end{array}$ & - & - & - & - & $\begin{array}{c}-1.0^{\star} \\
(-2.1 \text { to }-0.02)\end{array}$ \\
\hline & Male & All & $\begin{array}{c}1981-1987 \\
1.2 \\
(-1.7 \text { to } 4.2)\end{array}$ & $\begin{array}{c}1987-1990 \\
-6.5 \\
(-21.4 \text { to } 11.2)\end{array}$ & $\begin{array}{c}1990-1995 \\
4.3 \\
(-1.3 \text { to } 10.1)\end{array}$ & $\begin{array}{c}1995-2000 \\
-5.9^{\star} \\
(-11.0 \text { to }-0.6)\end{array}$ & $\begin{array}{c}2000-2015 \\
-1.5^{\star} \\
(-2.3 \text { to }-0.7)\end{array}$ & $\begin{array}{c}2015-2018 \\
-10.4^{\star} \\
(-17.8 \text { to }-2.3)\end{array}$ & $\begin{array}{c}-2.1^{\star} \\
(-3.9 \text { to }-0.3)\end{array}$ \\
\hline & & $10-19$ & $\begin{array}{c}1981-2018 \\
-5.2^{\star} \\
(-5.9 \text { to }-4.5)\end{array}$ & - & - & - & - & - & $\begin{array}{c}-5.2^{\star} \\
(-5.9 \text { to }-4.5)\end{array}$ \\
\hline & & $20-34$ & $\begin{array}{c}1981-1995 \\
-0.6 \\
(-2.0 \text { to } 0.8)\end{array}$ & $\begin{array}{c}1995-2005 \\
-7.7^{\star} \\
(-10.2 \text { to }-5.1)\end{array}$ & $\begin{array}{c}2005-2018 \\
-2.2^{\star} \\
(-3.7 \text { to }-0.6)\end{array}$ & - & - & - & $\begin{array}{c}-3.1^{\star} \\
(-4.1 \text { to }-2.1)\end{array}$ \\
\hline & & $35-64$ & $\begin{array}{c}1981-2010 \\
-0.7^{\star} \\
(-1.2 \text { to }-0.3)\end{array}$ & $\begin{array}{c}2010-2018 \\
-5.5^{\star} \\
(-8.2 \text { to }-2.6)\end{array}$ & - & - & - & - & $\begin{array}{c}-1.8^{\star} \\
(-2.5 \text { to }-1.1)\end{array}$ \\
\hline & & $65+$ & $\begin{array}{c}1981-2018 \\
-0.7^{\star} \\
(-1.2 \text { to }-0.3)\end{array}$ & - & - & - & - & - & $\begin{array}{c}-0.7^{\star} \\
(-1.2 \text { to }-0.3)\end{array}$ \\
\hline \multirow[t]{7}{*}{$\begin{array}{l}\text { Firearms or } \\
\text { explosives }\end{array}$} & Both & All & $\begin{array}{c}1981-1993 \\
-2.1^{\star} \\
(-3.0 \text { to }-1.3)\end{array}$ & $\begin{array}{c}1993-2005 \\
-6.2^{*} \\
(-7.1 \text { to }-5.3)\end{array}$ & $\begin{array}{c}2005-2018 \\
-1.6^{\star} \\
(-2.4 \text { to }-0.9)\end{array}$ & - & - & - & $\begin{array}{c}-3.3^{\star} \\
(-3.8 \text { to }-2.8)\end{array}$ \\
\hline & Female & All & $\begin{array}{c}1981-2008 \\
-7.4^{\star} \\
(-8.8 \text { to }-6.1)\end{array}$ & $\begin{array}{c}2008-2018 \\
1.0 \\
(-5.3 \text { to } 7.7)\end{array}$ & - & - & - & - & $\begin{array}{c}-5.2^{\star} \\
(-7.1 \text { to }-3.4)\end{array}$ \\
\hline & Male & All & $\begin{array}{c}1981-1993 \\
-2.1^{\star} \\
(-3.0 \text { to }-1.3)\end{array}$ & $\begin{array}{c}1993-2007 \\
-5.7^{\star} \\
(-6.4 \text { to }-5.0)\end{array}$ & $\begin{array}{c}2007-2018 \\
\quad-0.7 \\
(-1.7 \text { to } 0.3)\end{array}$ & - & - & - & $\begin{array}{c}-3.1^{\star} \\
(-3.6 \text { to }-2.6)\end{array}$ \\
\hline & & $10-19$ & $\begin{array}{c}1981-1993 \\
-2.3 \\
(-5.6 \text { to } 1.2)\end{array}$ & $\begin{array}{c}1993-2004 \\
-11.2^{\star} \\
(-15.2 \text { to }-7.0)\end{array}$ & $\begin{array}{c}2004-2018 \\
-1.5 \\
(-4.1 \text { to } 1.3)\end{array}$ & - & - & - & $\begin{array}{c}-4.7^{\star} \\
(-6.6 \text { to }-2.8)\end{array}$ \\
\hline & & $20-34$ & $\begin{array}{c}1981-1992 \\
-2.8^{\star} \\
(-4.5 \text { to }-1.0)\end{array}$ & $\begin{array}{c}1992-2008 \\
-8.7^{\star} \\
(-9.7 \text { to }-7.7)\end{array}$ & $\begin{array}{c}2008-2018 \\
2.4^{\star} \\
(0.3 \text { to } 4.6)\end{array}$ & - & - & - & $\begin{array}{c}-4.0^{\star} \\
(-4.9 \text { to }-3.2)\end{array}$ \\
\hline & & $35-64$ & $\begin{array}{c}1981-1993 \\
-1.8^{\star} \\
(-2.5 \text { to }-1.0)\end{array}$ & $\begin{array}{c}1993-2008 \\
-4.9^{*} \\
(-5.5 \text { to }-4.4)\end{array}$ & $\begin{array}{c}2008-2015 \\
0.9 \\
\text { (-1.2 to } 2.9)\end{array}$ & $\begin{array}{c}2015-2018 \\
-7.8^{\star} \\
(-13.2 \text { to }-2.1)\end{array}$ & - & - & $\begin{array}{c}-3.1^{\star} \\
(-3.7 \text { to }-2.4)\end{array}$ \\
\hline & & $65+$ & $\begin{array}{c}1981-2018 \\
-2.4^{\star} \\
(-2.7 \text { to }-2.1)\end{array}$ & - & - & - & - & - & $\begin{array}{c}-2.4^{\star} \\
(-2.7 \text { to }-2.1)\end{array}$ \\
\hline
\end{tabular}

Note: $\mathrm{AAPC}=$ average annual percent change between 1981 and 2018, APC = annual percent change within each temporal trend, $\mathrm{Cl}=$ confidence interval. *Statistical significance. 


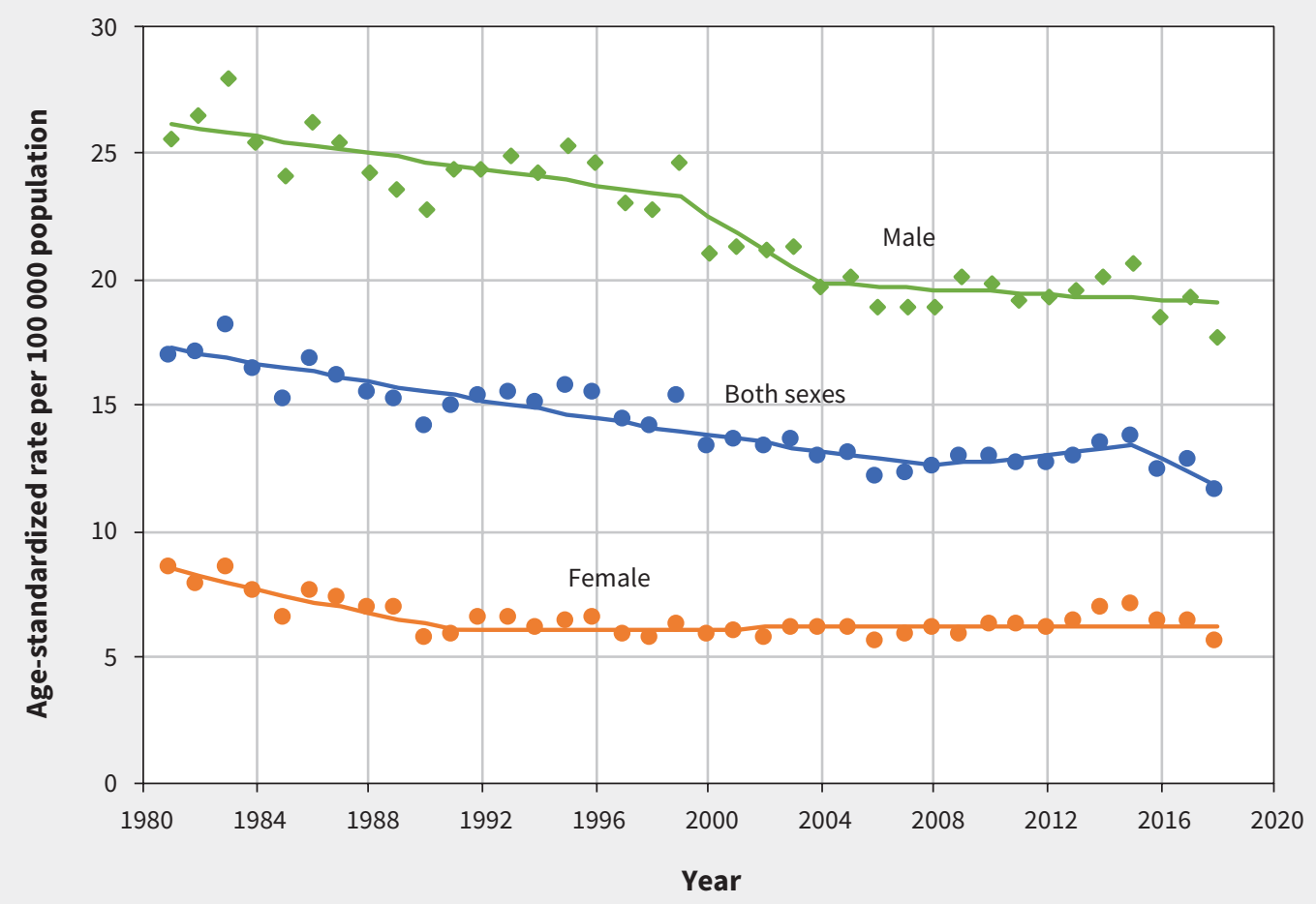

Figure 2: Age-standardized suicide mortality rates by sex in Canada, 1981-2018.

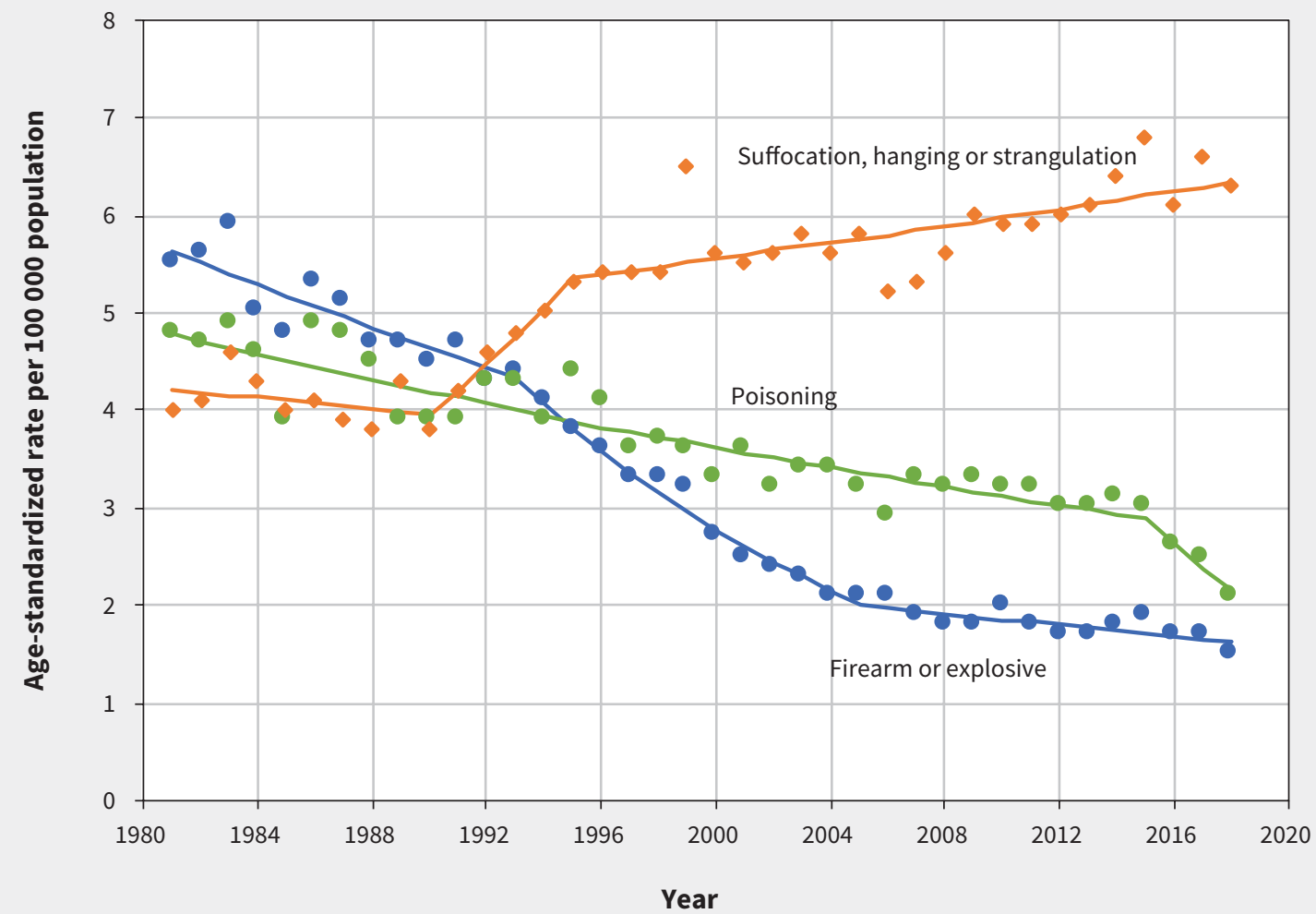

Figure 3: Age-standardized mortality rates of suicide by suffocation, hanging or strangulation; poisoning; and firearms or explosives in Canada for both sexes, 1981-2018. 
the use of the undetermined-intent category over time. ${ }^{9,25,26}$ More research is needed to understand these potential issues and other explanations (e.g., increased use of psychiatric medications that are less lethal when overdoses are attempted). ${ }^{27}$ We present results for 4 age groups, but findings might have varied had different age categories been examined. ${ }^{8}$ Additional studies could also examine variations in suicide rates by means over time by other sociodemographic characteristics (e.g., marital status). Finally, the most recent data available for analysis at the time of writing were from 2018 and we were therefore not able to examine the impact of coronavirus disease 2019 on patterns of suicide in Canada; its potential impact warrants urgent investigation..$^{28,29}$

\section{Conclusion}

The current analysis of suicide deaths from 1981 to 2018 yields greater understanding of recent and long-term changes in means of suicide in Canada. Although the suicide rate is lower than it was in the 1980s, the significant number of Canadians who die by suicide each year and the increasing suffocation suicide rate reinforces the importance of suicide prevention as a public health and safety issue in Canada. Although means restriction might have partially contributed to declines in the firearm and poisoning suicide rates, and may be feasible for preventing suffocation suicide deaths within institutions (such as correctional facilities and hospitals), the widespread physical accessibility of means of suffocation in the community makes restriction a less realistic suicide prevention strategy for the general population. ${ }^{30} \mathrm{~A}$ range of suicide prevention strategies, including those aimed at reducing cognitive accessibility (e.g., safe messaging and responsible media guidelines), improving mental health literacy and awareness of mental health supports, and addressing upstream risk and protective factors may be needed to reverse the worrying trend of increasing suffocation suicide mortality rates. ${ }^{7,31}$

\section{References}

1. Naghavi M; Global Burden of Disease Self-Harm Collaborators. Global, regional, and national burden of suicide mortality 1990 to 2016: systematic analysis for the Global Burden of Disease Study 2016. BMJ 2019;364: 194.

2. Varin M, Orpana HM, Palladino E, et al. Trends in suicide mortality in Canada by sex and age group, 1981 to 2017: a population-based time series analysis. Can J Psychiatry 2020 July 14 [Epub ahead of print]. doi: 10.1177/0706743720940565.

3. Table 13-10-0394-01: Leading causes of death, total population, by age group. Ottawa: Statistics Canada. Available: www150.statcan.gc.ca/t1/tbl1/en/tv. action?pid=1310039401 (accessed 2020 Apr. 6)

4. Ajdacic-Gross V, Weiss MG, Ring M, et al. Methods of suicide: international suicide patterns derived from the WHO mortality database. Bull World Health Organ 2008;86:726-32.

5. Skinner R, McFaull S, Draca J, et al. Suicide and self-inflicted injury hospitalizations in Canada (1979 to 2014/15). Health Promot Chronic Dis Prev Can 2016;36:243-51.

6. Navaneelan T. Health at a Glance: Suicide rates - an overview. Cat no 82-624-X. Ottawa: Statistics Canada; 2012. Available: www150.statcan.gc.ca/n1/pub/ 82-624-x/2012001/article/11696-eng.pdf (accessed 2020 Apr. 7).

7. Florentine JB, Crane C. Suicide prevention by limiting access to methods: a review of theory and practice. Soc Sci Med 2010;70:1626-32.

8. Skinner R, McFaull S. Suicide among children and adolescents in Canada: trends and sex differences, 1980-2008. CMAJ 2012;184:1029-34.

9. Skinner R, McFaull S, Rhodes AE, et al. Suicide in Canada: Is poisoning misclassification an issue? Can J Psychiatry 2016;61:405-12.
10. Preventing suicide: a global imperative. Geneva: World Health Organization; 2014. Available: www.who.int/mental_health/suicide-prevention/world_ report_2014/en/ (accessed 2020 Apr. 6).

11. Table 13-10-0098-01: Mental health characteristics and suicidal thoughts. Ottawa: Statistics Canada. Available: www150.statcan.gc.ca/t1/tbl1/en/tv. action?pid=1310009801 (accessed 2020 Apr. 6).

12. Schrijvers DL, Bollen J, Sabbe BGC. The gender paradox in suicidal behavior and its impact on the suicidal process. J Affect Disord 2012;138:19-26.

13. Suicide in Canada: key statistics [infographic]. Ottawa: Public Health Agency of Canada; modified 2020 Mar. 4. Available: www.canada.ca/en/public-health/ services/publications/healthy-living/suicide-canada-key-statistics-infographic.html (accessed 2020 Dec. 9).

14. Comparability of ICD-10 and ICD-9 for mortality statistics in Canada. Ottawa: Statistics Canada; 2005. Available: www150.statcan.gc.ca/n1/en/catalogue/ 84-548-X (accessed 2020 Apr. 7).

15. Anderson RN, Miniño AM, Hoyert DL, et al. Comparability of cause of death between ICD-9 and ICD-10: preliminary estimates. Natl Vital Stat Rep 2001;49:1-32.

16. Table 13-10-0156-01: Deaths, by cause, Chapter XX: External causes of morbidity and mortality (V01 to Y89). Ottawa: Statistics Canada. Available: www150.statcan.gc.ca/t1/tbl1/en/tv.action?pid=1310015601 (accessed 2020 May 4).

17. Table 17-10-0005-01: Population estimates on July 1st, by age and sex. Ottawa: Statistics Canada. Available: www150.statcan.gc.ca/t1/tbl1/en/tv. action?pid=1710000501 (accessed 2020 May 4).

18. Kim H-J, Fay MP, Feuer EJ, et al. Permutation tests for joinpoint regression with applications to cancer rates. Stat Med 2000;19:335-51.

19. Baker SP, Hu G, Wilcox HC, et al. Increase in suicide by hanging/suffocation in the U.S., 2000-2010. Am J Prev Med 2013;44:146-9.

20. Puzo Q, Qin P, Mehlum L. Long-term trends of suicide by choice of method in Norway: a joinpoint regression analysis of data from 1969 to 2012. BMC Public Health 2016;16:255.

21. Spicer RS, Miller TR. Suicide acts in 8 states: incidence and case fatality rates by demographics and method. Am J Public Health 2000;90:1885-91.

22. Causes of death, 2017. The Daily. Ottawa: Statistics Canada; 2019. Available: www150.statcan.gc.ca/n1/daily-quotidien/190530/dq190530c-eng.htm (accessed 2020 Apr. 4)

23. Santaella-Tenorio J, Cerdá M, Villaveces A, et al. What do we know about the association between firearm legislation and firearm-related injuries? Epidemiol Rev 2016;38:140-57.

24. Pettrone K, Curtin SC. Urban-rural differences in suicide rates, by sex and three leading methods: United States, 2000-2018. NCHS Data Brief No 373. Hyattsville (MD): National Center for Health Statistics; 2020. Available: www.cdc.gov/nchs/products/databriefs/db373.htm (accessed 2020 Dec. 1).

25. Esty A, Frize M, McFaull SR, et al. Classification of undetermined deaths by poisoning: comparison of homogeneous and heterogeneous databases. Ottawa: Canadian Medical and Biological Engineering Society. CMBES Proc 2017;40. Available: https://proceedings.cmbes.ca/index.php/proceedings/article/ view/608 (accessed 2020 Apr. 7).

26. Frize $\mathrm{M}$, Martirosyan $\mathrm{H}$, Subaskaran J, et al. Classification of undetermined deaths by poisoning: suicidal or unintentional. In: Kyriacou E, Christofides S, Pattichis C, editors. XIV Mediterranean Conference on Medical and Biological Engineering and Computing 2016. IFMBE Proceedings, Vol 57. Cham (Switzerland): Springer.

27. Hawton K, Bergen H, Simkin S. Toxicity of antidepressants: rates of suicide relative to prescribing and non-fatal overdose. Br J Psychiatry 2010;196: 354-8.

28. Reger MA, Stanley IH, Joiner TE. Suicide mortality and coronavirus disease 2019: A perfect storm? JAMA Psychiatry 2020 Apr. 10 [Epub ahead of print]. doi: 10.1001/jamapsychiatry.2020.1060.

29. McIntyre RS, Lee Y. Projected increases in suicide in Canada as a consequence of COVID-19. Psychiatry Res 2020;290:113104.

30. Gunnell D, Bennewith O, Hawton K, et al. The epidemiology and prevention of suicide by hanging: a systematic review. Int J Epidemiol 2005;34: 433-42.

31. Zalsman G, Hawton K, Wasserman D, et al. Suicide prevention strategies revisited: 10-year systematic review. Lancet Psychiatry 2016;3:646-59. 
Competing interests: None declared.

This article has been peer reviewed.

Affiliations: Centre for Surveillance and Applied Research (Liu, Capaldi, Orpana, Tonmyr), Public Health Agency of Canada; School of Epidemiology and Public Health (Orpana), University of Ottawa, Ottawa, Ont.; Luskin School of Public Affairs (Kaplan), University of California, Los Angeles, Calif.; Department of Sociology and Anthropology (Tonmyr), Carleton University, Ottawa, Ont.

Contributors: Colin Capaldi drafted and revised the manuscript based on feedback received from all other authors and during the peer review process. Li Liu conducted statistical analyses and revised analyses based on feedback received from all other authors. All of the authors revised the manuscript critically for important intellectual content, gave final approval of the version to be published and agreed to be accountable for all aspects of the work.

Funding: Mark Kaplan's work on this study was partially supported by a grant from the Fulbright Specialist Program (FSP-P005326). None of the other authors received specific funding for this work.

Content licence: This is an Open Access article distributed in accordance with the terms of the Creative Commons Attribution (CC BY-NC-ND 4.0) licence, which permits use, distribution and reproduction in any medium, provided that the original publication is properly cited, the use is noncommercial (i.e., research or educational use), and no modifications or adaptations are made. See: https://creativecommons.org/ licenses/by-nc-nd/4.0/
Data sharing: Mortality data from 2000 to 2018 are publicly available online at https:// doi.org/10.25318/1310015601-eng. Requests to access the 1981 to 1999 mortality data should be made to Statistics Canada.

Acknowledgement: The authors thank Jodie Golden from the Public Health Agency of Canada for reviewing a draft of the manuscript for safe messaging.

Disclaimer: The findings and conclusions in this article are those of the authors and do not necessarily reflect the official positions of the Government of Canada.

Accepted: Dec. 22, 2020

Correspondence to: Colin Capaldi, colin.capaldi@canada.ca 